\title{
Cooperação intergovernamental, consórcios públicos e sistemas de distribuição de custos e benefícios
}

\author{
José Angelo Machado \\ Universidade Federal de Minas Gerais \\ Marta Leone Costa Andrade \\ Universidade Federal de Minas Gerais
}

\begin{abstract}
Neste trabalho, buscamos esclarecer como consórcios intermunicipais distribuem benefícios e custos entre seus associados, ponto relevante para estruturar a disposição à cooperação entre parceiros. Sob o estudo de casos em três áreas governamentais, identificamos dois padrões dos sistemas de compartilhamento de custos e benefícios. No primeiro, o contrato de rateio é restrito a despesas rotineiras do consórcio, enquanto contratos complementares com cada associado garantem contribuições, ex post, na proporção dos benefícios usufruídos. No segundo, o próprio contrato de rateio inclui critérios que permitem equalizar, ex ante, tais contribuições e benefícios. Ao final, consideramos restrições sobre funções desempenhadas pelos consórcios em políticas públicas, em decorrência da lógica pela qual cada associado paga pelo que consome.
\end{abstract}

Palavras-chave: relação intergovernamental; cooperação; consórcio público; problema distributivo.

Cooperación intergubernamental, consorcios públicos y sistemas de distribución de los costos y beneficios

En este trabajo se explica cómo consorcios intermunicipales distribuyen beneficios y costos entre los miembros, cuestión de relieve para estructurar la disposición a la cooperación entre los socios. Según estudio de situaciones en tres áreas gobernamentales, se identificaron dos normas para los sistemas de reparto de costes y beneficios. En una primera, el contrato de división se restringe a los gastos de rutina del consorcio mientras contratos complementares con cada asociado garantizan que cada uno contribuya, ex post, con los beneficios disfrutados. En la segunda, el propio contrato de división adopta criterios que permiten igualar, ex ante, tales contribuciones y beneficios. Al final tenemos en cuenta las restricciones a las funciones realizadas por los consorcios en la política pública debido a la lógica por la cual cada miembro paga por lo que consume.

Palabras Clave: relación intergubernamental; cooperación; consorcio público; problema distributivo.

DOI: http://dx.doi.org/10.1590/0034-76121626

Artigo recebido em 27 jun. 2013 e aceito em 13 fev. 2014.

Rev. Adm. Pública - Rio de Janeiro 48(3):695-720, maio/jun. 2014 
Intergovernmental cooperation, public consortia, and systems for distributing costs and benefits In this paper, we seek to clarify how intermunicipal consortia distribute benefits and costs among their members, a relevant point to structure the willingness to cooperation between partners. Under the case study in three government areas, we identify two patterns of the systems for sharing costs and benefits. In the first, the division agreement is restricted to routine expenses of the consortium, while additional agreements with each member ensure contributions, ex post, according to the proportion of benefits enjoyed. In the second, the division agreement itself includes criteria that allow equalizing, ex ante, such contributions and benefits. In the end, we consider restrictions on functions performed by consortia in public policies, due to the reasoning by which each member pays for what it consumes.

KEYWORDS: intergovernmental relation; cooperation; public consortium; distributive problem.

\section{Introdução}

Consórcios intergovernamentais são associações voluntárias entre entes governamentais para produção e compartilhamento de valores públicos, requerendo cooperação entre as partes interessadas na realização de objetivos comuns. Neste trabalho, sem prejuízo do reconhecimento da sua importância para viabilizar a provisão de serviços públicos em diversas áreas governamentais, dada a fragmentação política decorrente do federalismo trino brasileiro, tratamos de um ponto ainda obscuro: de que maneira consórcios intergovernamentais que proveem valores públicos de natureza diversa distribuem benefícios e custos entre associados? Tal problema se apoia sobre a constatação de que determinados valores públicos — como os não fracionáveis ou aqueles cujo consumo não é programável — podem tornar incertos os níveis de participação nos benefícios entre associados. E se há incerteza quanto à participação nos benefícios, o desenho das regras que distribuem os custos de produção entre os entes associados pode se tornar problemático ao elevar os riscos de que uns se apropriem de rendas ou de frações da produção conjunta disponíveis a outros. Assim, supondo que entes governamentais não sejam indiferentes a tais riscos, seria de se esperar que a estabilização das formas institucionais erigidas nos consórcios requeira adoção de critérios e normas distributivas que os afastem.

Tomamos como hipótese central que, a despeito da diversidade de valores públicos a serem produzidos e compartilhados, há necessidade de mecanismos institucionais que equalizem a distribuição de custos e benefícios entre membros de uma associação intergovernamental. Para sua verificação escolhemos três áreas de ação governamental — saúde, saneamento e desenvolvimento socioeconômico ${ }^{1}$ — e, para cada uma delas, selecionamos três consórcios intermunicipais. A escolha destes se restringiu à região Sudeste, ${ }^{2}$ considerando facilidades logísticas para comunicação e acesso a documentos, caso necessário. Além disso, somente consórcios autodeclarados no inquérito do Instituto Brasileiro de Geografia e Estatística (IBGE)

\footnotetext{
${ }^{1}$ A escolha buscou intencionalmente variar a natureza dos valores públicos ofertados aos associados.

${ }^{2}$ O Sudeste concentra mais de $40 \%$ das participações municipais em consórcios intermunicipais, segundo inquéritos realizados pelo IBGE a partir dos anos 2000.
} 
como públicos foram incluídos, restringindo o estudo àqueles que já tivessem formatado seu sistema de compartilhamento de custos e benefícios sob os efeitos da Lei dos Consórcios ou Lei nº 11.107/2005. A exclusão de consórcios envolvendo outras esferas de governo, que não os municípios, visou restringir o estudo às "associações entre iguais", isolando casos em que a participação de uma esfera de governo mais abrangente, com responsabilidades distintas na respectiva política pública, inserisse outras variáveis que pudessem confundir a análise acerca das questões distributivas entre associados.

Para cada consórcio pesquisado foi levantado um conjunto de informações a partir das quais organizamos um banco de dados, incluindo denominação; atividades que realiza; ano de fundação e de reformulação regimental para adequação à Lei no 11.107/2005; número de municípios consorciados; município sede; população coberta; extensão territorial; critério adotado para contribuição e beneficiamento; forma de transferência dos recursos municipais para o consórcio.

Ao final constatamos que os sistemas de compartilhamento de custos e benefícios encontrados nos diversos casos se estruturam basicamente de duas formas. Na primeira, o contrato de rateio entre municípios consorciados se restringe às despesas fixas para assegurar o funcionamento do consórcio e, por meio de contratos complementares, os associados repassam, ex post, parcelas de contribuição variáveis na medida do montante de benefícios efetivamente consumidos, sejam consultas médicas, exames, toneladas de lixo sólido processadas ou outros serviços opcionais. Na segunda, o próprio contrato de rateio adota algum critério que permite estimar, ex ante, a participação dos diversos associados nos benefícios e, daí, fixar sua participação nos custos, como ocorreu no estabelecimento de contribuições proporcionais ao número de ligações de água em consórcios de saneamento focados no seu fornecimento. Sob qualquer uma dessas duas formas, a distribuição de custos e de benefícios entre associados permite evitar choques de interesses entre eles, assumindo lógica similar à de mercado onde cada um paga pelo que consome. Tais formas institucionais parecem restringir bastante as possibilidades de que consórcios intergovernamentais, enquanto mecanismo de cooperação, possam se prestar a resolver problemas distributivos ou na perspectiva da região tomada como uma unidade e não como somatória de municípios.

Na primeira parte do trabalho relacionamos algumas das contribuições relevantes para o tratamento da temática dos consórcios intergovernamentais, identificando a existência de uma lacuna no que se refere a estudos que abordem problemas distributivos entre associados, para o que apresentamos o marco teórico a ser utilizado em nossa análise. Na segunda, caracterizamos a trajetória dos consórcios na administração pública brasileira e, na terceira, apresentamos algumas considerações preliminares sobre o impacto da recém-implementada Lei dos Consórcios. Na quarta apresentamos propriamente os resultados e análise pertinentes aos estudos de casos e, na quinta, nossas considerações finais.

\section{Consórcios intermunicipais, cooperação e problemas distributivos}

A presença dos consórcios intergovernamentais, no contexto da administração pública brasileira, ganhou um novo capítulo após a promulgação da Constituição Federal de 1988, quando 
os municípios foram elevados à condição de ente federado. Nessa nova fase, os consórcios se tornaram alvo do interesse de pesquisadores e especialistas em temáticas como federalismo, relações intergovernamentais ou políticas públicas. Não obstante, a produção acadêmica pertinente é ainda recente, sendo a maior parte datada do início do século XXI, com poucos trabalhos publicados na década de 1990, com destaque para algumas dissertações e teses desenvolvidas em universidades e fundações de ensino e pesquisa. A produção sobre essa temática tende a se tornar ainda mais esparsa na medida em que se refira a aspectos específicos dos consórcios: variações nas formas institucionais; novos atributos emergentes a partir da figura do consórcio de direito público, criado pela Lei no 11.107; o papel indutor da União ou dos estados ou, mesmo, a participação direta dessas esferas nessas associações, dentre outros. Quanto às áreas governamentais abrangidas, grande parte dos trabalhos refere-se à saúde, o que pode ser creditado em grande medida ao pioneirismo e à escala com que suas experiências se difundiram nos municípios, principalmente na região Sudeste.

Dos trabalhos mais relevantes, boa parte se dedica à descrição de experiências bemsucedidas, trazendo elementos conceituais que permitam elucidar a natureza dessas associações ou agrupamentos em que vários interessados na promoção de uma política pública a implementam de forma compartilhada, sobre as bases da cooperação e negociação. É o caso de "Redes federativas no Brasil: cooperação intermunicipal no Grande ABC" (Abrucio e Soares, 2001), onde são contextualizados como parte de um processo de formação de redes federativas ou redes intergovernamentais, estabelecidas no plano horizontal a partir do processo de redemocratização do país. Com foco na experiência da região do Grande $\mathrm{ABC}$, a análise se concentra nos mecanismos de cooperação intergovernamentais ali existentes, entre os quais o Consórcio Intermunicipal das Bacias do Alto Tamanduateí e Billings, conhecido como Consórcio Intermunicipal Grande ABC.

Do ponto de vista da distribuição da produção bibliográfica entre as diversas áreas governamentais, é notório que a maioria focaliza os consórcios intermunicipais de saúde. Entre as contribuições voltadas para esse setor, Ribeiro e Costa (2000) descreveram os atributos dos consórcios de saúde no Brasil nos anos 1990 e suas potencialidades na organização das redes assistenciais, ampliação das capacidades de governo e maior eficiência na oferta dos serviços, destacando a experiência fundadora do Consórcio Intermunicipal de Saúde de Penápolis. Lima (2000), por sua vez, enfatizou a distribuição dos consórcios de saúde entre regiões e estados brasileiros, bem como suas características organizacionais e jurídicas. Outras contribuições são circunscritas às experiências com consórcios em determinadas unidades da federação, permitindo introduzir novos elementos. Scheneider (2001) analisou as experiências do estado do Rio de Janeiro, identificando as diferentes finalidades e processos de formação dos consórcios, bem como as variações nas estruturas administrativas. Rocha e Faria (2004) analisam a experiência de Minas Gerais, onde se concentrou e se concentra ainda hoje a maior parte dos consórcios do país, destacando o papel do governo estadual e levantando outros fatores facilitadores do processo de cooperação. Em outra direção, Santos (2002) analisou sua pertinência na organização das redes de atenção no âmbito do Sistema Único de Saúde (SUS) destacando os aspectos jurídicos a serem observados em sua construção. Em contraste 
com o setor saúde, a despeito de a Constituição de 1988 preconizar o regime de colaboração para organização dos sistemas de ensino em cada esfera de governo, o setor educacional tem utilizado pouco os consórcios públicos, aspecto abordado por Abrucio e Ramos (2012).

Considerando os consórcios intergovernamentais como instrumentos privilegiados de cooperação no âmbito da federação brasileira, Cunha (2004) focou a necessidade de constituição de um marco legal para sua consolidação, considerando os termos da reforma administrativa estabelecidos pela Emenda Constitucional no 19, de 15 de junho de 1995, bem como destacou os principais aspectos da regulamentação dos consórcios públicos e as polêmicas em jogo. Essa discussão teve continuidade, sob os desdobramentos da Lei no 11.107/2005, no trabalho "Consórcios Públicos: instrumento do federalismo cooperativo" (Pires e Barbosa, 2008). Os autores discutem os consórcios públicos do ponto de vista normativo, jurídico e administrativo, além de discorrer, principalmente em sua primeira parte, sobre aspectos do federalismo brasileiro, descentralização e cooperação, evidenciados no texto constitucional. Na mesma direção, Ravanelli (2010) faz um balanço dos benefícios trazidos pela referida lei, em especial do ponto de vista da segurança jurídica para os entes associados, uma vez definidos claramente os termos de entrada e saída da associação, bem como suas obrigações e responsabilidades.

Mais recentemente, um balanço dos efeitos da Lei no 11.107/2005 na disseminação e distribuição dos consórcios públicos foi empreendido no trabalho "Cooperação federativa: a formação de consórcios entre entes públicos no Brasil” (Ipea, 2010), no qual os autores utilizam dados da Pesquisa do IBGE sobre municípios.

Não obstante esse amplo conjunto de aspectos abordados pela literatura pertinente aos consórcios, pouca atenção tem sido dada a temas tipicamente abordados na literatura sobre relações intergovernamentais, como os problemas de agência (Levaggi, 2002; Oates, 2005), cooperação e conflitos distributivos (Scharpf, 1997) ou responsabilização nas parcerias cooperativas (Löffler, 2000). O tratamento desses temas se mostra de grande relevância para a análise da dinâmica das relações entre os entes governamentais associados por meio de consórcios e, daí, de fenômenos relacionados à estabilidade ou instabilidade das formas institucionais adotadas, à expansão ou retração da formação de consórcios, dentre outros. Sua introdução na abordagem dos consórcios apresenta valor heurístico, portanto, ao transpor o caráter restritamente descritivo dos estudos e permitir a construção de hipóteses explicativas acerca de eventos ou efeitos percebidos.

Neste particular, entendemos ser pertinente privilegiar duas referências teóricas, que irão alimentar este trabalho do ponto de vista analítico: a dos problemas de ação coletiva e a do neoinstitucionalismo. O recurso à primeira decorre de que consórcios intergovernamentais envolvem a cooperação dos entes governamentais para realização de interesses comuns. O recurso à última decorre de que a própria solução de problemas de ação coletiva requeira, por sua vez, uma construção institucional capaz de viabilizar a produção do bem público e constranger eventuais comportamentos dispersivos ou "traições" entre associados, o que coloca o problema da escolha das formas institucionais. Até o final desta seção, ajustaremos nosso foco em cada uma dessas referências. 
Partindo dos problemas de ação coletiva, é sabido que os estudos sobre ação coletiva se referem a um conjunto bastante heterogêneo de empreendimentos que inclui o interacionismo simbólico da Escola de Chicago, passando pelos marxistas e pós-marxistas, até chegar ao trabalho seminal de Mancur Olson Júnior. Para este último, diferentemente da tradição sociológica antecedente, ${ }^{3}$ a cooperação com a ação coletiva não é tomada, por pressuposto, como caminho natural dos indivíduos com interesses comuns, uma vez que a deserção também seria uma opção racional quando estiverem envolvidos bens públicos (Olson Júnior, 1968). Para esse autor, o bem público típico seria aquele que uma vez assegurado a uma parcela do conjunto de indivíduos seria, necessariamente, disponível aos demais, sem que o consumo possa ser negado aos mesmos. No caso de ser o objeto da ação coletiva, cooperando ou não, um indivíduo com interesses comuns aos demais poderia, portanto, usufruir o bem público sem que tivesse que absorver os custos da sua produção. E na hipótese de se beneficiar sem cooperar, o indivíduo se comportaria como um free rider surgindo, daí, o clássico dilema da ação coletiva. Essa abrangeria, portanto, situações-problema em que, numa comunidade de indivíduos com interesses comuns, a estratégia de cooperação com a ação coletiva esteja ameaçada pela alternativa do comportamento "carona", que uma vez difundido pode pôr em risco a própria produção do bem público.

Nas relações intergovernamentais, este achado tem implicações óbvias: não se poderia esperar que, mesmo tendo interesses em comum, a cooperação fosse o único comportamento esperado por parte dos governos envolvidos, embora caibam aqui duas observações. Em primeiro lugar, tomados em sentido mais amplo, problemas de ação coletiva não necessariamente exigiriam que o interesse comum entre governos se dirigisse a um típico bem público, até porque estes são mais raros que outros tipos de bens compartilhados que não se enquadram na clássica definição de Olson. Em segundo lugar, nas relações intergovernamentais não seria apenas o comportamento free rider que ameaçaria a ação coletiva, tornando a alternativa da deserção atraente: pressões domésticas com riscos eleitorais, ${ }^{4}$ ou a possibilidade de obter o benefício por outras vias também poderiam ter efeito similar. O que é relevante para o presente estudo é que consórcios intergovernamentais lidam com contextos de ação coletiva onde os riscos de comportamentos do tipo free rider ou os conflitos quanto à absorção de custos ou acesso a benefícios também podem vir a ser relevantes.

\footnotetext{
${ }^{3}$ Neste conjunto de abordagens as preocupações foram diversas. Se para a Escola de Chicago importava realçar a formação da identidade de grupo nos contextos de conflito entre diferentes estratos sociais e culturais, para os marxistas a discussão se vinculou em grande medida ao conceito de luta de classes e à constituição destas na transposição da esfera econômica para a política, deixando de ser apenas uma classe em si para se tornar uma classe para si (Gohn, 2004). Já pós-marxistas como Claus Offe focaram temas como os novos movimentos sociais surgidos a partir dos anos 1970 .

${ }^{4}$ Esta possibilidade se enquadra naquilo que Tsebelis (1998) denomina jogo da representação, considerando que o representante se insere em pelo menos duas arenas - da barganha com outros representantes (arena da representação) e da disputa com outros concorrentes, a representante (arena eleitoral) - e que, nesta circunstância, suas escolhas numa arena devam levar em conta os resultados produzidos na outra.
} 
Neste ponto a referência ao neoinstitucionalismo torna-se fundamental, uma vez que as interações entre governos envolvidos em problemas de ação coletiva são reguladas pelas instituições, aqui tomadas mais amplamente como regras que definem quem são os agentes, quais as estratégias ou jogadas possíveis e quais os resultados que decorrem de cada uma delas (Tsebelis, 1998). Como tais, estas regras produziriam resultados estáveis na medida em que, estabelecendo sanções positivas ou negativas, afetariam o cálculo estratégico dos agentes induzindo-os a assumir um determinado padrão de comportamento (Knight, 2001). Na indução do comportamento cooperativo para promoção da ação coletiva, sanções institucionais deveriam afetar tal cálculo a ponto de superar a disposição individual de minimizar esforços e maximizar benefícios usufruídos, problema discutido por Miller e Hammond (1994) ao apontar os limites de formas institucionais fundadas em sanções coercitivas ou em incentivos positivos estruturados por um administrador central. Consórcios intergovernamentais, de modo similar, estruturam regras que regulam interações e que podem induzir, com maior ou menor eficácia, comportamentos cooperativos por parte de seus membros.

É neste ponto que introduzimos o problema da cooperação nas associações para produção, proposto por Scharpf (1997): envolvendo simultaneamente as dimensões da produção e distribuição de valores, no processo de constituição das regras institucionais, a falta de acordo quanto ao aspecto distributivo é capaz de retroagir e inviabilizar acordos já concluídos quanto ao aspecto produtivo. Agentes sociais não seriam indiferentes aos efeitos distributivos das regras institucionais: quais esforços devem despender e quanto podem se beneficiar da ação coletiva, vis-à-vis os demais agentes a ela incorporados. ${ }^{5}$ Poderiam até mesmo aquiescer diante de acordos desfavoráveis sob condições adversas quando não tiverem alternativa que os levem a resultados melhores (Knight, 2001), mas existindo tal hipótese, o contrato constitutivo da associação para ação coletiva poderia ser desfeito, inviabilizando a dos valores a serem compartilhados.

Transpondo o problema para a constituição dos consórcios intergovernamentais, é de se esperar que suas formas institucionais incluam sistemas de compartilhamento de benefícios e custos que estabeleçam algum nível de equivalência entre ambos no tratamento dos associados, prevenindo que alguns possam auferir benefícios em proporção maior ou menor do que a da sua participação relativa nos custos da parceria. Problemas decorrentes da ausência dessa equivalência marcam a história dos consórcios no caso brasileiro, como na pioneira experiência do Consórcio de Penápolis (Ribeiro e Costa, 2000), quando se discutia entre os associados se as contribuições deveriam se dar na proporção das suas populações ou do número de atendimentos efetivamente dispensado à população de cada município. As assimetrias de porte populacional e de níveis de consumo dos serviços do consórcio colocaram em lados opostos o município de Penápolis e os demais associados.

\footnotetext{
${ }^{5}$ A literatura sobre problemas de cooperação chama atenção para o fato de que a escolha do comportamento cooperativo não seja incondicional, dependendo, portanto, de que os outros também cooperem, do que se depreende o caráter interdependente das escolhas aí envolvidas (Schelling, 1964; Axelrod e Keohane, 1985; Reis e Castro, 2001).
} 
Considerando a diversidade da natureza dos valores públicos que são objeto da parceria entre governos locais, Löffler (2000) introduziu nuances adicionais quanto aos incentivos institucionais para a cooperação. Para essa autora, basicamente três tipos de parceria são relevantes quanto ao tipo de bem ou serviço público: associações para produção conjunta de utilidades distribuídas aos associados com ganhos de escala, associações para gestão de recursos comuns por meio de ação regulatória do seu uso e associações para investimento conjunto visando retornos de longo prazo para associados. A disponibilidade, ou não, de informações ex ante sobre a participação ex post nos benefícios pelos vários associados poderia variar entre os diferentes tipos, envolvendo distintos graus de incerteza e, daí, diferentes alternativas para a construção de regras pelas quais se estabelecem as relações entre outorgantes e outorgados, como na distribuição dos custos da parceria entre associados.

Postos sumariamente esses dois referenciais, pode-se perceber o contraste entre sua relevância teórica e sua notável ausência da literatura brasileira acerca dos consórcios intergovernamentais. Neste trabalho temos por objetivo dar uma singela contribuição na direção de aproximá-los. Para tanto buscamos identificar de que maneira consórcios intergovernamentais, focando valores públicos de natureza distinta, estariam construindo seus respectivos sistemas de compartilhamento de benefícios e custos. Antes, porém, de abordar o que os estudos de casos teriam a nos dizer a este respeito, retomaremos uma descrição da trajetória dos consórcios na administração pública brasileira, a fim de apontar os elementos mais importantes do marco constitucional e legal em que se estabeleceram, bem como uma análise preliminar da sua difusão recente entre diferentes áreas de políticas públicas, onde se constroem para prover diferentes bens e serviços públicos.

\section{Consórcios intermunicipais na administração pública brasileira}

Embora admitido em constituições estaduais, ${ }^{6}$ no final do século XIX, com a instauração da República, foi na década de 1930 que, em dimensão nacional, o agrupamento de municípios para realização de serviços públicos comuns foi admitido pela primeira vez no ordenamento jurídico brasileiro. Já as primeiras experiências bem-sucedidas com consórcios públicos remontam ao interior do estado de São Paulo nos anos 1960, especialmente em atividades ligadas às áreas de promoção social e desenvolvimento. Nos anos 1980, ainda antes da Constituição Federal de 1988, os consórcios começaram a se disseminar no setor saúde, espelhandose no caso de Penápolis, em São Paulo, criado em 1986, e sua expansão foi em grande medida influenciada pela indução das Secretarias de Estado da Saúde, aspecto que será retomado neste trabalho:

\footnotetext{
${ }^{6}$ Cunha (2004) lembra que o art. 56 da Constituição Paulista de 1891 já previa a associação de municipalidades para realização de melhoramentos de interesse comum, porém condicionada à aprovação do Legislativo estadual.
} 
A expansão dos CIS, num primeiro momento, foi discreta, tendo sido influenciada pela divulgação nacional da experiência de Penápolis por grande parte dos adeptos do municipalismo na saúde e graças à simpatia pela ideia por parte do então ministro da Saúde, Adib Jatene, que a defendeu em seu discurso à IX Conferência Nacional de Saúde como estratégia para imprimir racionalidade à municipalização da saúde. Num segundo momento, especialmente a partir da segunda metade dos anos 90, houve uma ampliação intensa dos CIS, exatamente quando impulsionados pela atuação de algumas Secretarias de Estado da Saúde. (Machado, 2007:71)

Na mesma década, no setor de desenvolvimento econômico e social, somente no estado de São Paulo, foram criados cinco consórcios, ${ }^{7}$ alguns com atuação também na área de saúde, envolvendo um total de 90 municípios (Cepam, 2009).

Enquanto associações entre dois ou mais municípios cooperando entre si para a execução de serviços públicos comuns, os consórcios ganharam respaldo na Constituição de 1988 e se expandiram como um modelo de gestão descentralizada na busca de racionalização dos recursos públicos, conforme destacado por Cruz, Araújo e Batista (2011:112):

Após a Constituição de 1988 e da promulgação de algumas leis que a regulamentam, essas formas têm sido utilizadas com maior frequência com o objetivo de racionalizar os recursos locais e regionais e como um modelo de gestão. Nesse contexto de reforma do Estado e de incentivo à descentralização das políticas públicas, os consórcios intermunicipais têm sido difundidos e representam parcerias entre governos locais.

No setor saúde eles se expandiram de maneira intensa nos anos 1990. Segundo Lima (2000), em sete estados analisados no ano de 1997 (Minas Gerais, Paraná, Paraíba, Mato Grosso, São Paulo, Rio Grande do Sul e Santa Catarina) havia 91 consórcios, abrangendo 1.204 municípios. Ao final da década já eram 141 associações distribuídas por 13 estados da federação, englobando 1.618 municípios e 25.376.829 cidadãos (Lima e Pastrana, 2000).

Embora nem sempre a denominação "consórcio" tenha sido utilizada, seu uso preserva, em essência, a ideia de compartilhamento de interesses comuns entre entes governamentais, seja em escala vertical — entre União, estados e municípios —, seja em escala horizontal — quando interestaduais ou intermunicipais. A adesão de entes governamentais a um consórcio é voluntária, preservando sua autonomia política. O quadro 1 apresenta a trajetória dos consórcios e de outras formas de cooperação entre governos locais com respectivas normatizações no texto de diversas constituições brasileiras.

\footnotetext{
${ }^{7}$ Consórcio Intermunicipal do Vale do Paranapanema (Civap), Consórcio de Desenvolvimento da Região de Governo de São João da Boa Vista (Conderg), Consórcio de Desenvolvimento Intermunicipal do Vale do Ribeira (Codivar), Consórcio de Municípios da Alta Mogiana (Coman) e Consórcio Intermunicipal dos Vales dos Rios Tietê-Paraná.
} 


\section{Quadro 1 \\ Prerrogativas constitucionais para desenvolvimento da cooperação entre entes da federação na República brasileira}

\begin{tabular}{|c|c|c|c|}
\hline & Marco legal & Denominação & Abrangência \\
\hline 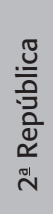 & $\begin{array}{l}\text { Decreto } \text { n}^{\circ} 23.611 \text {, } \\
\text { de } 20-12-1933\end{array}$ & $\begin{array}{l}\text { Consórcios profissio- } \\
\text { nais-cooperativos }\end{array}$ & $\begin{array}{l}\text { Art. } 7 \text { o - Os consórcios profissionais-cooperativos poderão constituir } \\
\text { uniões municipais, federais estaduais e confederações nacionais, } \\
\text { desde que de uma mesma finalidade econômico-profissional, e terão } \\
\text { personalidade jurídica separada e gozarão dos mesmos direitos e } \\
\text { vantagens dos consórcios profissionais-cooperativos isolados. }\end{array}$ \\
\hline 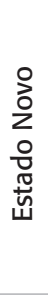 & $\begin{array}{l}\text { Constituição de } \\
1937\end{array}$ & $\begin{array}{l}\text { Agrupamentos de } \\
\text { municípios }\end{array}$ & $\begin{array}{l}\text { Art. } 29 \text { - Os municípios da mesma região podem agrupar-se para a } \\
\text { instalação, exploração e administração de serviços públicos comuns. O } \\
\text { agrupamento, assim constituído, será dotado de personalidade jurídica } \\
\text { limitada a seus fins. } \\
\text { Parágrafo único - Caberá aos Estados regular as condições em que } \\
\text { tais agrupamentos poderão constituir-se, bem como a forma, de sua } \\
\text { administração. }\end{array}$ \\
\hline \multirow{2}{*}{ 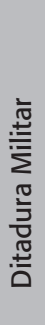 } & $\begin{array}{l}\text { Constituição de } \\
1967\end{array}$ & Convênios & $\begin{array}{l}\text { Art. 16, § 40 - Os Municípios poderão celebrar convênios para a } \\
\text { realização de obras ou exploração de serviços públicos de interesse } \\
\text { comum, cuja execução ficará dependendo de aprovação das respectivas } \\
\text { Câmaras Municipais. }\end{array}$ \\
\hline & $\begin{array}{l}\text { Emenda Consti- } \\
\text { tucional no 1, de } \\
1969\end{array}$ & & $\begin{array}{l}\text { Art. 13, § 3ํ - A União, os Estados e Municípios poderão celebrar } \\
\text { convênios para execução de suas leis, serviços ou decisões, por } \\
\text { intermédio de funcionários federais, estaduais ou municipais. }\end{array}$ \\
\hline \multirow{4}{*}{ 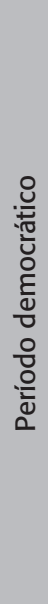 } & $\begin{array}{l}\text { Constituição de } \\
1988\end{array}$ & $\begin{array}{l}\text { Consórcios públicos e } \\
\text { convênios }\end{array}$ & $\begin{array}{l}\text { Art. } 241 \text { - A União, os Estados, o Distrito Federal e os Municípios } \\
\text { disciplinarão por meio de lei os consórcios públicos e os convênios de } \\
\text { cooperação entre os entes federados, autorizando a gestão associada } \\
\text { de serviços públicos, bem como a transferência total ou parcial de } \\
\text { encargos, serviços, pessoal e bens essenciais à continuidade dos } \\
\text { serviços transferidos. }\end{array}$ \\
\hline & $\begin{array}{l}\text { Lei no } 11.107 \text {, de } \\
\text { 6-4-2005 }\end{array}$ & $\begin{array}{l}\text { Consórcios públicos } \\
\text { (1), e }\end{array}$ & $\begin{array}{l}\text { Art. 1 Dispõe sobre normas gerais para a União, os Estados, o Distrito } \\
\text { Federal e os Municípios contratarem consórcios públicos para a } \\
\text { realização de objetivos de interesse comum; }\end{array}$ \\
\hline & & $\begin{array}{l}\text { Consórcios adminis- } \\
\text { trativos (2) }\end{array}$ & $\begin{array}{l}\S 1 \text { 1 O consórcio público constituirá associação pública ( } 1 \text { ) ou pessoa } \\
\text { jurídica de direito privado (2). }\end{array}$ \\
\hline & $\begin{array}{l}\text { Decreto no } 6.017 \text {, } \\
\text { de } 17-1-2007\end{array}$ & & $\begin{array}{l}\text { Regulamenta a Lei no } 11.107 \text {, de } 6 \text { de abril de 2005, que dispõe sobre } \\
\text { normas gerais de contratação de consórcios públicos. }\end{array}$ \\
\hline
\end{tabular}

Fonte: Elaboração própria a partir das Constituições brasileiras.

Conforme se pode observar no quadro 1, as formas de cooperação entre os entes federados (União e estados) e não federados (municípios) anteriores ao período democrático cul- 
minavam na constituição de associações civis, podendo participar de sua composição o poder público mas também, em alguns casos, agentes privados. Tais associações ou agrupamentos são similares àquelas formas atualmente denominadas consórcios administrativos: associações de direito privado formadas por dois ou mais entes, pessoas jurídicas de direito público, com o propósito de compartilhar atribuições e responsabilidades comuns em algumas áreas de políticas públicas. Ressalta-se que somente no período democrático é que os municípios foram reconhecidos como entes da federação dotados de autonomia política e fiscal.

Dallabrida e Zimermann (2009) entendem que as formas de cooperação entre os três níveis federados (União, estados e municípios) têm sido moldadas por vetores relacionados 1) à formação do nosso sistema federativo; 2) ao processo de centralização/descentralização político-administrativa; e 3) à fragmentação territorial resultante da criação de novos estados e municípios. Especialmente em relação a este último aspecto, vale lembrar que no art. 23 da Constituição Federal de 1988, em seu parágrafo único, foi definido que normas para cooperação entre União, estados e municípios seriam fixadas em lei complementar. Posteriormente, o art. 241 da Constituição Federal — estabelecido pela Emenda Constitucional no 19/1998 — fixou obrigação para que União, estados e municípios disciplinassem, por lei, a participação em consórcios e convênios de cooperação que autorizassem a gestão associada de serviços públicos. Foi no sentido de regulamentar esse dispositivo que teve origem a Lei no 11.107/2005, também denominada Lei dos Consórcios Públicos, regulamentada dois anos depois por meio do Decreto Presidencial no 6.017/2007. A percepção de necessidade de regulamentação legal para o funcionamento dos consórcios se baseava em que, a despeito de apresentarem-se largamente difundidos na administração pública, eram fragilizados institucionalmente pela pendente regulamentação jurídica prevista pelo texto constitucional. Segundo o relatório Pesquisa de Informações Básicas Municipais (IBGE, 2005), "Os consórcios têm sido utilizados na solução de um amplo espectro de problemas municipais e regionais e também por um número cada vez maior de municípios. Ainda que largamente usados, (...) carecem de bases legais sólidas" (IBGE, 2005:40).

A regulamentação da Lei, através do Decreto nำ 6.017, ocorrido em 17 de janeiro de 2007, denomina consórcio público como:

Pessoa jurídica formada exclusivamente por entes da Federação, na forma da Lei no 11.107, de 2005, para estabelecer relações de cooperação federativa, inclusive a realização de objetivos de interesse comum, constituída como associação pública, com personalidade jurídica de direito público e natureza autárquica, ou como pessoa jurídica de direito privado sem fins econômicos. (Art. 2으, inciso I)

Para que o consórcio público se constitua é necessária manifestação de interesse por parte do ente federativo através de Protocolo de Intenções e ratificação pelo Poder Legislativo daquela jurisdição. Deste modo, a referida lei favoreceu maior transparência, uma vez que tais instrumentos devem estabelecer claramente os limites da autorização concedida ao consórcio para representá-los, bem como as regras para tomada de decisão em assembleias gerais. Se, por um lado, essa remodelação dos consórcios públicos privilegiou a dimensão horizontal 
destas parcerias, dispondo de instrumentos para obtenção de maior confiança entre parceiros, por outro, formalizou a possibilidade de participação dos estados e da União, condicionando a participação desta última no consórcio público aos casos em que o estado ao qual se vinculam os municípios consorciados faça parte deste consórcio (art. 36 do Decreto ㄲo 6.017/2007).

A lei determinou também, por meio do seu art. 13, que os consórcios públicos estariam obrigados a observar, estritamente, as normas de direito público em processos de compras e contratação de serviços e de pessoal. Além disso, estabeleceu o mecanismo básico pelo qual os consorciados repartiriam os custos da associação, para cada exercício financeiro, por ela denominado contrato de rateio. Esse seria formulado a partir da previsão global anual de gastos do consórcio, base para o rateio entre os associados.

De acordo com o Decreto regulamentador, em seu art. 3ํㅡ, os objetivos de interesse comum incluiriam a gestão associada de serviços públicos; ações e políticas de desenvolvimento urbano, socioeconômico local e regional; compartilhamento ou uso em comum de instrumentos e equipamentos, procedimentos de licitação e de admissão de pessoal; promoção do uso racional dos recursos naturais e proteção do meio ambiente; exercício de funções no sistema de gerenciamento de recursos hídricos, desde que delegadas ou autorizadas.

Assim, o próprio marco constitucional e legal para funcionamento dos consórcios apontou explicitamente para uma diversidade de utilidades públicas a serem compartilhadas entre os entes governamentais associados, sendo notável a predominância de determinados tipos nas diferentes áreas de políticas públicas. Na próxima seção abordamos a evolução dos consórcios intermunicipais nestas áreas a partir da vigência da Lei dos Consórcios.

\section{A Lei no $11.107 / 2005$ e a difusão dos consórcios intermunicipais nas diversas áreas governamentais}

Grandes expectativas vêm sendo colocadas sobre a Lei dos Consórcios Públicos, especialmente quanto à maior segurança jurídica nas relações entre associados; maior confiabilidade e transparência realizadas sob o contrato de consórcio e contrato de rateio; menor propensão à instabilidade decorrente de variações sazonais de cunho político-eleitoral; ampliação da sua margem de atuação dos consórcios; além de maior possibilidade de transferência de recursos financeiros da União e dos estados para consórcios amparados pela nova regulamentação (Machado e Dantas, 2008).

As primeiras avaliações sobre o impacto da Lei dos Consórcios têm se ocupado de mensurar seu efeito disseminador (IBGE, 2012), indicando que esta tenha levado a um "avanço expressivo na quantidade de consórcios públicos” (Ipea, 2010:556). Tomando por referência levantamentos realizados pelo Instituto Brasileiro de Geografia e Estatística (IBGE), elas sugerem que os efeitos de emulação produzidos pela referida lei teriam se difundido "em todas as áreas de atuação, exceto na de transporte" (Ipea, 2010:563). A mesma análise, como se segue, tomando por base o número de participações de municípios em consórcios no ano de 2009, em comparação com o número relativo a 2005, atribui à percepção de segurança jurídica proporcionada pela referida Lei o motivo principal deste efeito: 
Todavia, em que pese o histórico de experiências cooperativas entre entes federados, o arranjo institucional disponível até 2005 tornava frágil qualquer ação, pela precariedade dos mecanismos de enforcement do compromisso assumido pelas partes. Nesse ano, o país passou a ser dotado de uma nova norma legal, que instituiu a figura do consórcio público, para o qual instrumentos mais poderosos de comprometimento dos entes consorciados foram estabelecidos. (Ipea, 2010:563)

Embora restringindo-nos aos consórcios intermunicipais, que aqui nos interessam mais de perto, a introdução de mais dois levantamentos realizados pelo IBGE, um anterior e outro posterior ao período analisado no estudo supracitado, realizados para os anos de 2002 e 2011, pode permitir levantar outras percepções sobre este mesmo processo.

\section{Gráfico 1 \\ Participações de municípios em consórcios intermunicipais no Brasil entre 2002 e $2011^{8}$}

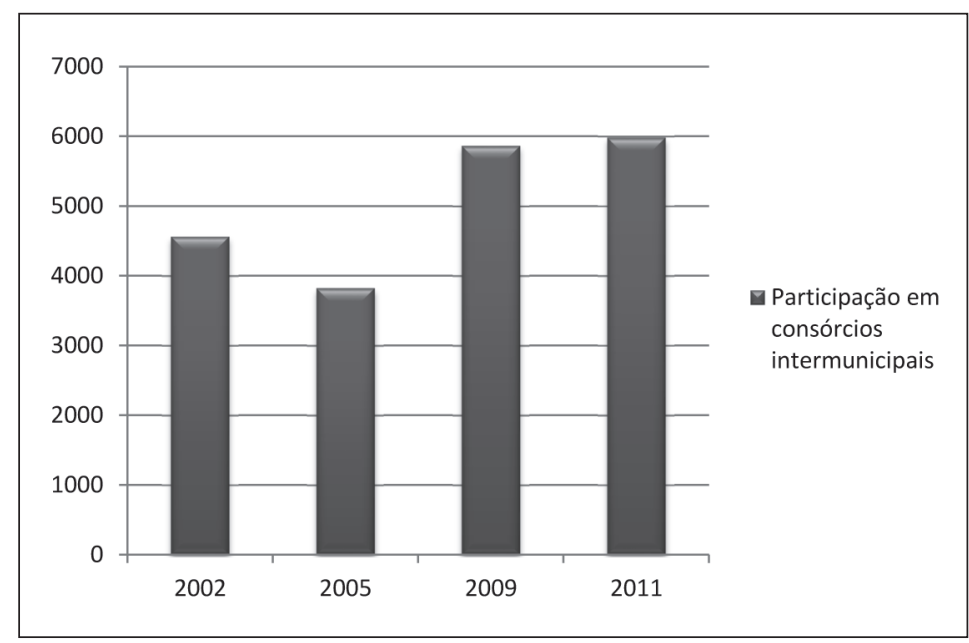

Fonte: Elaboração própria.

Analisando apenas os nove setores de políticas públicas que foram objeto dos quatro inquéritos realizados pelo IBGE, a fim de evitar um eventual viés produzido pela inclusão de

\footnotetext{
${ }^{8}$ O inquérito de 2011 distinguiu os consórcios públicos dos administrativos e, para efeito de comparabilidade com os anos anteriores, especialmente 2009, quando já seria possível aplicar esta distinção, contabilizamos ambos de forma agrupada. De acordo com esse inquérito, é consórcio administrativo aquele "constituído antes da Lei oㅜ 11.107", pelo que configura "pacto de mera colaboração (sem personalidade jurídica) ou associação civil, regida pelo direito privado, que poderá ser convertido para consórcio público". Já este último é “pessoa jurídica formada exclusivamente por entes federativos, na forma da Lei no 11.107, para estabelecer relações de cooperação federativa, inclusive a realização de objetivos de interesse comum, constituída como associação pública, com personalidade jurídica de direito público e natureza autárquica, ou como pessoa jurídica de direito privado sem fins econômicos".
} 
dois setores ${ }^{9}$ que foram investigados em apenas parte destes levantamentos, chegamos ao gráfico 1. Com base no mesmo, percebe-se que entre 2002 e 2005 houve uma significativa redução das participações em consórcios intermunicipais, de 4.563 para 3.823 participações, portanto, da ordem de 16,2\%. Trata-se exatamente do período antecedente à Lei dos Consórcios, cujos efeitos somente se fizeram sentir a partir de então.

Entre 2005 e 2009, por sua vez, houve uma intensa expansão nas participações, que saltaram para 5.864 neste último ano, com uma expansão no período da ordem de 53,4\%. Esse período recebe o impacto inicial da Lei dos Consórcios, que se desdobra no momento seguinte - entre 2009 e 2011 - para uma expansão por meio da qual se chegou a 5.981 participações, ou seja, um incremento da ordem de $2 \%$. Esse tímido incremento pode ter significados bem distintos: pode expressar a estagnação dos efeitos da Lei dos Consórcios ou até mesmo o início de um novo ciclo de retração das participações, assim como poderia expressar uma mera flutuação temporária, antes que se estabeleça um ponto de equilíbrio, ou mesmo um ciclo de crescimento estável mais moderado.

Embora futuros levantamentos do IBGE possam nos encaminhar em algumas dessas direções, a análise dos dados desagregados para os nove setores que fizeram parte dos inquéritos é bastante sugestiva. O gráfico 2 permite qualificar melhor as tendências gerais descritas: entre 2002 e 2005 houve retração nas participações municipais em seis dos nove setores; entre 2005 e 2009, em apenas um, mas entre 2009 e 2011 as participações municipais voltaram a cair para três dos nove setores estudados.

\section{Gráfico 2}

Participações de municípios em consórcios intermunicipais no Brasil entre 2002 e 2011 por setor governamental

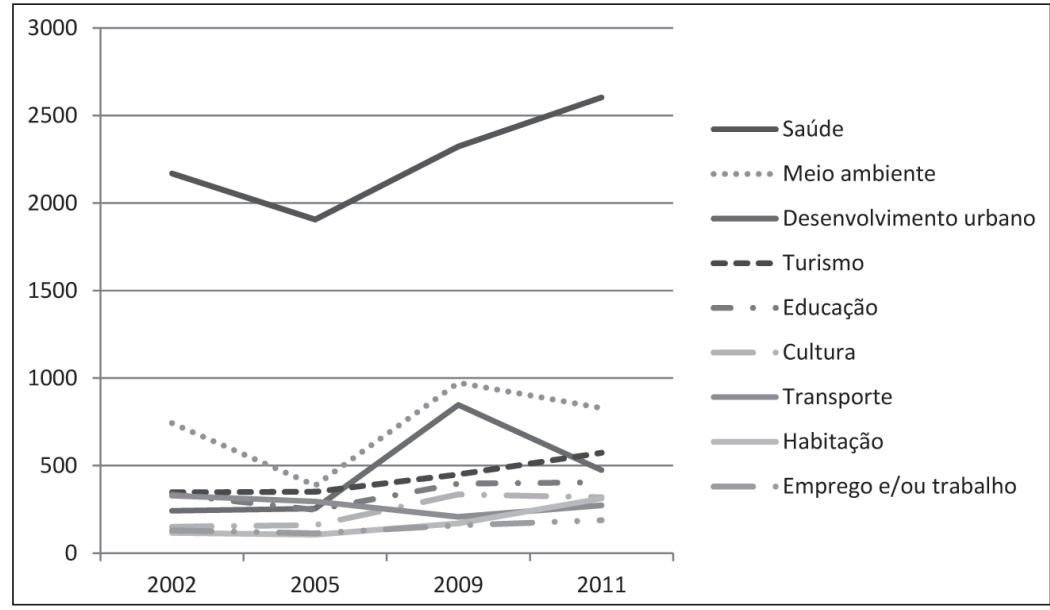

Fonte: Elaboração própria.

\footnotetext{
${ }^{9}$ Ficaram fora desse levantamento os setores assistência e desenvolvimento social e saneamento básico, que não entraram no inquérito do ano de 2009.
} 
Outra constatação de especial interesse para este trabalho diz respeito à distribuição relativa das participações em consórcios intermunicipais entre os diferentes setores governamentais ao longo do período estudado. ${ }^{10}$ Os gráficos 3A e 3B mostram que, entre 2002 e 2011, caiu a participação relativa dos maiores setores — saúde e meio ambiente - enquanto cresceu a de setores importantes como turismo, desenvolvimento urbano, educação, habitação e cultura.

\section{Gráfico 3 A}

Distribuição das participações de municípios em consórcios intermunicipais no Brasil em 2002, por setor governamental

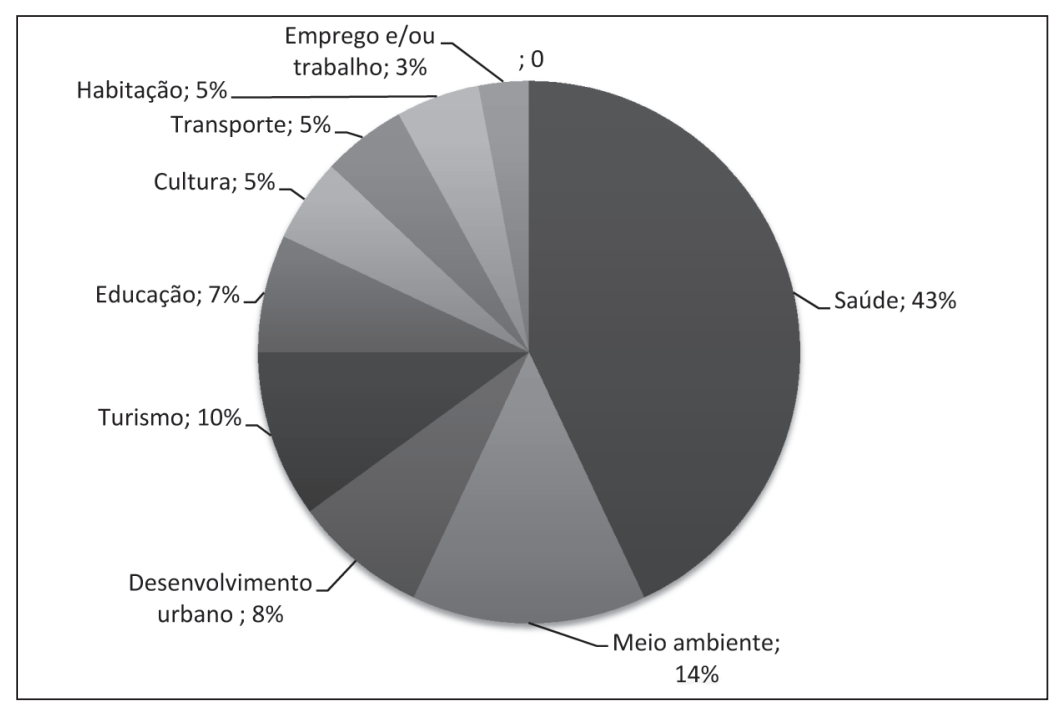

Fonte: Elaboração própria.

Deste modo, a diversidade na dinâmica de expansão ou contração das participações municipais nas diferentes áreas governamentais, nem sempre acompanhando a tendência geral, bem como as variações no peso relativo de cada uma, são indícios que sugerem presença de variáveis endógenas capazes de afetar as decisões de gestores locais quanto a participar ou não dos consórcios intermunicipais, aspecto ainda pouco explorado.

Uma dessas variáveis endógenas, com forte impacto na saúde, setor ainda responsável por mais de $40 \%$ nas participações em consórcios intermunicipais no país, pode ser a forte presença indutora dos governos estaduais (Ribeiro e Costa, 2000; Lima e Pastrana, 2000; Machado, 2007). Tomando como referência os consórcios de saúde contabilizados pelo Mi-

\footnotetext{
${ }^{10}$ Aqui incluímos os dois outros setores; em 2002, fez parte do inquérito o de desenvolvimento e assistência social e, em 2011, além deste, o setor de saneamento básico.
} 
nistério da Saúde para o ano de 2008 (Brasil, 2008), pode-se afirmar que em pelo menos três estados - Minas Gerais, Paraná e Mato Grosso — , representando cerca de 60\% de todos os consórcios brasileiros neste setor, houve, e há, uma ação intensa de indução e sustentação dos consórcios pelos governos estaduais, incluindo sua definição como estratégia de regionalização, oferta de convênios para gerir determinados tipos de serviços ou mesmo transferências financeiras diretas para investimentos de capital e para custeio. ${ }^{11}$

\section{Gráfico 3 B}

\section{Distribuição das participações de municípios em consórcios intermunicipais no Brasil em 2011, por setor governamental}

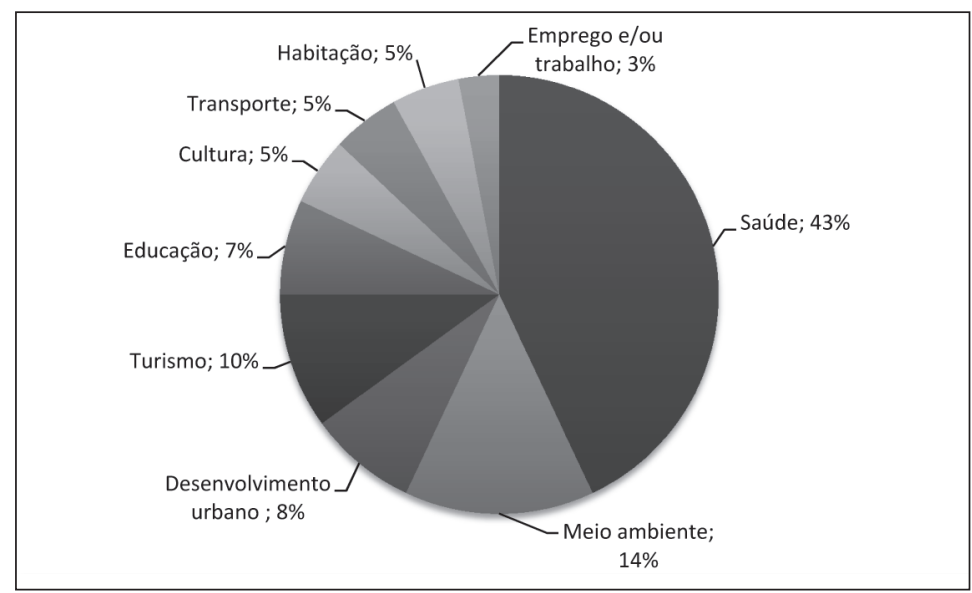

Fonte: Elaboração própria.

O levantamento de variáveis endógenas atuantes em outros setores é tarefa ainda a ser realizada. Não obstante, considerando a expansão e diversificação da participação nos consórcios intermunicipais nas diversas áreas governamentais, é perceptível que as associações entre municípios tenham se consolidado em algumas onde antes tinham presença marginal. Nelas ofertam as mais diversificadas utilidades públicas, abrangendo desde bens públicos típicos e indivisíveis até o uso compartilhado de equipamentos ou a produção de serviços consumidos na esfera individual, disponibilizados para cidadãos adscritos aos consórcios. Na próxima seção, considerando os problemas inerentes à barganha entre agentes governamentais para solução de problemas comuns, nos dedicaremos ao esforço para identificar quais as formas

\footnotetext{
${ }^{11}$ Informações referentes aos diversos tipos de apoio dado aos consórcios intermunicipais de saúde pelas respectivas Secretarias de Estado são acessíveis em: <www.saude.mg.gov.br/> (editais para financiamento de despesas de custeio e capital dos consórcios em Minas Gerais); em: <www.sesa.pr.gov.br/modules/conteudo/conteudo. php? conteudo $=2890>$ (programa de apoio a consórcios da Secretaria de Estado da Saúde do Paraná); e em: <www. seplan.mt.gov.br/sigcon/index_php?operacao=Exibir\&serv=legis/legislacao\&grupo=in\&lei=IN_01_10> (instrução normativa para convênios de cogestão entre consórcios e Secretaria de Estado da Saúde do Mato Grosso).
} 
construídas nestes diferentes setores para a distribuição de custos e benefícios entre os associados.

\section{Sistemas de compartilhamento de custos e benefícios em consórcios intermunicipais}

Os nove consórcios pesquisados abarcaram um total de 177 municípios participantes, cobrindo uma população total de 11.512 .123 habitantes e uma extensão territorial de $81.458 \mathrm{~km}^{2}$, conforme consolida a tabela 1 .

$$
\text { Tabela } 1
$$

Municípios*, população coberta e extensão territorial de abrangência dos consórcios pesquisados por setor governamental

\begin{tabular}{|lccc|}
\hline \multicolumn{1}{|c}{ Setores } & $\begin{array}{c}\text { № municípios parti- } \\
\text { cipantes }\end{array}$ & População coberta & $\begin{array}{c}\text { Extensão territorial } \\
\left(\mathrm{Km}^{2}\right)\end{array}$ \\
\hline Saúde & 84 & 6.262 .206 & 37.643 \\
Saneamento & 58 & 2.120 .953 & 30.051 \\
Desenvolvimento socioeconômico & 35 & 3.128 .964 & 13.764 \\
Total & 177 & 11.512 .123 & 81.458 \\
\hline
\end{tabular}

Fonte: IBGE (2010).

* Consideramos aqui os municípios que fazem parte do consórcio conforme divulgado em seus sites e/ou seus respectivos contratos de consórcios.

Os três quadros, a seguir, apresentam informações referentes a cada um dos nove consórcios pesquisados, incluindo atividades realizadas, ano de fundação e ano em que foi reformulado como consórcio público, bem como o critério adotado para contribuições/beneficiamento e o mecanismo usado para transferência de recursos.

$$
\text { Quadro } 2 \mathrm{~A}
$$

Atributos de três casos de consórcios estudados na área da saúde

\begin{tabular}{|lllc|}
\hline $\begin{array}{c}\text { Fundação/ } \\
\text { adequação lei }\end{array}$ & \multicolumn{1}{c}{ Atividade } & Critério contribuições-benefícios & $\begin{array}{c}\text { Mecanismo de } \\
\text { transferência de } \\
\text { recursos }\end{array}$ \\
\hline $1996-2010$ & Cirurgias eletivas, consultas e exa- & Contrato de rateio para manutenção & Débito automático \\
& mes especializados & da estrutura fixa do consórcio, sendo a & em conta do \\
& contribuição de cada um fixada por critério & município mediante \\
& populacional. Os serviços efetivamente & autorização junto à \\
& prestados para cada município são pagos à & instituição financeira. \\
& parte após a prestação. & \\
\hline
\end{tabular}

Continua 


\begin{tabular}{|c|c|c|c|}
\hline $\begin{array}{c}\text { Fundação/ } \\
\text { adequação lei }\end{array}$ & Atividade & Critério contribuiç̧ões-benefícios & $\begin{array}{l}\text { Mecanismo de } \\
\text { transferência de } \\
\text { recursos }\end{array}$ \\
\hline $2011-11$ & Implantação do Samu regional & $\begin{array}{l}\text { É estimado um valor fixo variável por } \\
\text { município acrescido de } R \$ 0,25 / \text { habitante } \\
\text { proporcional à sua população: } \\
\text { até } 20.000 \text { hab.: } R \$ 500,00 \text { mensais + } \\
R \$ 0,25 / \text { hab.; } \\
\text { 20.001-50.000 hab.: } R \$ 1.000,00+ \\
R \$ 0,25 / \text { hab.; } \\
\text { 20.001-100.000 hab.: } R \$ 1.500,00+ \\
R \$ 0,25 / \text { hab.; } 100.001-300.000 \text { hab.: } \\
R \$ 2.500,00+R \$ 0,25 / \text { hab.; acima de } \\
300.000 \text { hab.: } R \$ 5.000,00+R \$ 0,25 / \text { hab. }\end{array}$ & $\begin{array}{l}\text { Repasse mensal por } \\
\text { transferência bancária } \\
\text { ao consórcio. }\end{array}$ \\
\hline 2009-09 & $\begin{array}{l}\text { Atendimento de urgências e emer- } \\
\text { gências; transporte de usuários; } \\
\text { ações e serviços preventivos e } \\
\text { assistência de abrangência local; } \\
\text { serviços assistenciais de segundo e } \\
\text { terceiro nível de complexidade. }\end{array}$ & $\begin{array}{l}\text { Contrato de Rateio formalizado } \\
\text { estabelecendo percentuais } \\
\text { proporcionalmente às populações dos } \\
\text { municípios consorciados. Mediante preços } \\
\text { de procedimentos fixados em assembleia, } \\
\text { o consórcio firma contratos de prestação } \\
\text { de serviço com os municípios associados, } \\
\text { que transferem os recursos conforme a } \\
\text { produção que lhes foi destinada. }\end{array}$ & $\begin{array}{l}\text { Repasse mensal por } \\
\text { transferência bancária } \\
\text { ao consórcio. }\end{array}$ \\
\hline
\end{tabular}

Fonte: Elaboração própria.

\section{Quadro 2 B}

\section{Atributos de três casos de consórcios estudados na área de saneamento}

\begin{tabular}{|c|c|c|c|}
\hline $\begin{array}{c}\text { Fundação/ } \\
\text { adequação } \\
\text { lei }\end{array}$ & Atividade & Critério contribuições-benefícios & $\begin{array}{l}\text { Mecanismo de } \\
\text { transferência de } \\
\text { recursos }\end{array}$ \\
\hline $2011-11$ & $\begin{array}{l}\text { Manejo de resíduos sólidos e } \\
\text { drenagem urbana, inclusive aterros } \\
\text { sanitários conjuntos; assessoria } \\
\text { jurídica e contábil; controle da } \\
\text { qualidade da água; elaboração de } \\
\text { projetos de engenharia; atendi- } \\
\text { mento aos Saaes em situações } \\
\text { emergenciais. }\end{array}$ & $\begin{array}{l}\text { Municípios contribuem conforme } \\
\text { enquadramento em faixas de utilização dos } \\
\text { serviços, sendo a Faixa } 1 \text { um valor fixo acrescido } \\
\text { das outras faixas para o excedente: } \\
\text { FAIXA 1: Até 2.000 ligações de água } \\
\text { (R\$ 800,00); FAIXA 2: } 2.001 \text { a } 4.000 \text { ligações } \\
\text { (+ R\$ 0,35/ligação); FAIXA 3: } 4.001 \text { a } 6.000 \\
\text { ligações (+ R\$ 0,30/ligação); FAIXA 4: } 6.001 \text { a } \\
\text { 15.000 (+ R\$ 0,20/ligação); } \\
\text { FAIXA 5: acima de 15.001 (+ R\$ 0,10 por } \\
\text { ligação). }\end{array}$ & $\begin{array}{l}\text { Repasse mensal } \\
\text { por transferência } \\
\text { bancária ao } \\
\text { consórcio. }\end{array}$ \\
\hline 2008-08 & $\begin{array}{l}\text { Serviços de apoio aos serviços de } \\
\text { saneamento básico, através de ca- } \\
\text { pacitação de pessoal e assistência } \\
\text { técnica, a cada um dos municípios } \\
\text { consorciados. }\end{array}$ & $\begin{array}{l}\text { Os entes consorciados contribuem mediante } \\
\text { contrato com o Consórcio para prestação de } \\
\text { serviços, execução de obras ou fornecimento } \\
\text { de bens e mediante contrato de rateio no qual } \\
\text { o valor proposto para cada município é de } R \$ \\
0,35 \text { para até } 3.000 \text { ligações e R\$ 0,25 para o } \\
\text { restante das ligações existentes. }\end{array}$ & $\begin{array}{l}\text { Repasse mensal } \\
\text { por transferência } \\
\text { bancária ao } \\
\text { consórcio. }\end{array}$ \\
\hline
\end{tabular}




\begin{tabular}{|c|c|c|c|}
\hline $\begin{array}{l}\text { Fundação/ } \\
\text { adequação } \\
\text { lei }\end{array}$ & Atividade & Critério contribuiç̣ões-benefícios & $\begin{array}{l}\text { Mecanismo de } \\
\text { transferência de } \\
\text { recursos }\end{array}$ \\
\hline 2009-09 & $\begin{array}{l}\text { Implantação, operação e utilização } \\
\text { de aterro sanitário destinado à cor- } \\
\text { reta disposição dos resíduos sólidos } \\
\text { domiciliares, comerciais e públicos. }\end{array}$ & $\begin{array}{l}\text { Os entes consorciados entregarão recursos } \\
\text { do contrato de rateio (critério populacional) } \\
\text { complementando com pagamento, cujo cálculo } \\
\text { é proporcional ao resíduo gerado, pesado no } \\
\text { aterro sanitário. }\end{array}$ & $\begin{array}{l}\text { Repasse mensal } \\
\text { por transferência } \\
\text { bancária ao } \\
\text { consórcio. }\end{array}$ \\
\hline
\end{tabular}

Fonte: Elaboração própria.

$$
\text { Quadro } 2 \text { C }
$$

\section{Atributos de três casos de consórcios estudados na área de desenvolvimento social}

\begin{tabular}{|c|c|c|c|}
\hline $\begin{array}{c}\text { Fundação/ } \\
\text { adequação } \\
\text { lei }\end{array}$ & Atividade & Critério contribuiç̧ões-benefícios & $\begin{array}{l}\text { Mecanismo de } \\
\text { transferência de } \\
\text { recursos }\end{array}$ \\
\hline 2006-06 & $\begin{array}{l}\text { Obras públicas, trânsito e transporte; Meio } \\
\text { Ambiente; Educação; Saúde; Esporte e Lazer; } \\
\text { Comunicação; Cultura; Desenvolvimento Rural; } \\
\text { Desenvolvimento Social; Desenvolvimento } \\
\text { Econômico; Defesa Social; Apoio Jurídico; } \\
\text { Gestão Administrativa; Rede Corporativa } \\
\text { de Dados; Capacitação de Servidores; } \\
\text { Compartilhamento de Compras e outros. }\end{array}$ & $\begin{array}{l}\text { Prefeituras consorciadas repassam } \\
\text { recursos para despesas ordinárias } \\
\text { por meio do contrato anual de rateio } \\
\text { (critério populacional) e contratam } \\
\text { programas específicos, para os quais } \\
\text { existe livre adesão, podendo também } \\
\text { existir participação externa de outros } \\
\text { entes de governo e empresas. }\end{array}$ & $\begin{array}{l}\text { Repasse mensal } \\
\text { por transferência } \\
\text { bancária ao } \\
\text { consórcio. }\end{array}$ \\
\hline 1990-2010 & $\begin{array}{l}\text { Apoio à Infraestrutura, Desenvolvimento } \\
\text { econômico, Desenvolvimento urbano e gestão } \\
\text { ambiental, Saúde; Educação, cultura e esportes; } \\
\text { Assistência, inclusão social e direitos humanos; } \\
\text { Segurança pública - ações desenvolvidas são } \\
\text { aprovadas em Grupos de Trabalho específicos } \\
\text { em cada um destes eixos, formados pelos } \\
\text { municípios consorciados. }\end{array}$ & $\begin{array}{l}\text { Orçamento e planos plurianuais } \\
\text { aprovados em assembleia dos } \\
\text { consorciados definem o rateio } \\
\text { (critério populacional), além do que } \\
\text { os municípios transferem recursos } \\
\text { em conformidade com projetos } \\
\text { atendidos. }\end{array}$ & $\begin{array}{l}\text { Repasse mensal } \\
\text { por transferência } \\
\text { bancária ao } \\
\text { consórcio. }\end{array}$ \\
\hline 1985-2008 & $\begin{array}{l}\text { Meio ambiente: destinação de resíduos sólidos } \\
\text { e tecnológicos (Eco Valeverde); cursos e } \\
\text { palestras de capacitação em diversas áreas } \\
\text { (Escola de governo); Saneamento: asfaltamento } \\
\text { e recapeamento das vias públicas (Patrulha } \\
\text { asfáltica) }\end{array}$ & $\begin{array}{l}\text { A contribuição fixada para rateio } \\
\text { entre os municípios é calculada por } \\
\text { faixa populacional, além da qual há } \\
\text { repasse mensal para manutenção } \\
\text { dos projetos, aos quais os municípios } \\
\text { aderem voluntariamente. }\end{array}$ & $\begin{array}{l}\text { Repasse mensal } \\
\text { por pagamento } \\
\text { de boleto emitido } \\
\text { pelo consórcio. }\end{array}$ \\
\hline
\end{tabular}

Fonte: Elaboração própria.

A análise dos consórcios intermunicipais vinculados aos três setores oferece elementos bastante esclarecedores para um melhor conhecimento dos sistemas de compartilhamento de benefícios e custos utilizados para valores compartilhados de natureza distinta.

Começando pelo setor saúde, a cesta de serviços oferecida aos consorciados é variada: em um deles, apenas procedimentos eletivos ou programáveis (consultas especializadas, 
cirurgias e exames); em outro, apenas o atendimento móvel de urgência, via Samu; e, no último, atendimentos de urgência/emergência (não programáveis) combinados com procedimentos eleitos ou programáveis em diferentes níveis de complexidade assistencial (transporte de pacientes, ações preventivas e atendimentos individuais). No primeiro e no terceiro casos, a despeito dos diferentes tipos de utilidades, o sistema de compartilhamento segue o mesmo padrão: rateio das despesas fixas da estrutura do consórcio com contribuições proporcionais à população dos municípios e pós-pagamento por procedimentos e serviços realizados pelo consórcio para cada associado. O segundo caso, que foge a esse padrão, contempla apenas o rateio das despesas fixas do consórcio por meio de um cálculo que envolve uma parcela fixa, por faixa populacional, e outra, variável, não ficando claro, nos instrumentos normativos analisados, como os associados compensariam o consórcio pelos serviços efetivamente prestados a cada um. ${ }^{12}$

No setor de saneamento, os dois primeiros consórcios analisados lidam com sistemas de distribuição e de coleta da água utilizada, incluindo assessoria jurídica e técnica, capacitação de pessoal, ações de controle da qualidade da água, dentre outros. O terceiro se destina exclusivamente ao tratamento de resíduos sólidos e gestão de aterro sanitário, embora o primeiro também possa abranger projetos para manejo de resíduos sólidos. Nos dois primeiros, o sistema de compartilhamento utiliza como critério para o rateio o número de ligações de água, o que permite, em alguma medida, equacionar custos individuais aos benefícios auferidos por município. No terceiro, o contrato de rateio (de base populacional) se restringe à contribuição para as despesas fixas de manutenção do consórcio, mas os associados vão complementar os recursos transferidos para o consórcio na proporção do resíduo sólido, que é pesado no próprio aterro sanitário.

O setor de desenvolvimento socioeconômico encara um desafio diferente dos dois anteriores: são consórcios multitemáticos ou multissetoriais, dada a natureza ampla ou diversificada do seu objeto. Isto implica que todos eles compreendem um amplo leque de atividades, embora essa amplitude varie entre os casos analisados, podendo envolver a realização de obras públicas de infraestrutura, ações ambientais ou culturais, ações de estruturação das próprias prefeituras, capacitação de servidores ou apoio técnico e jurídico, dentre outros. A fórmula do sistema de compartilhamento é ao mesmo tempo simples e flexível nos três casos analisados: um contrato de rateio de base populacional entre os municípios consorciados para as despesas fixas e pagamentos adicionais decorrentes da adesão dos mesmos aos projetos ofertados pelos consórcios para cada tipo de atividade.

As características dos sistemas de compartilhamento de benefícios e custos analisados nos três setores demonstram que em todos eles os consórcios se adaptaram à exigência de

\footnotetext{
${ }^{12}$ Embora formalmente a Secretaria de Estado da Saúde não participe do consórcio, ao longo da pesquisa tivemos informação de que ela assumiria a parte dos custos referente à remuneração variável dos serviços prestados. Há a possibilidade de que, na hipótese de que esse consórcio incorpore outras ações de saúde, os municípios distribuam o custeio das mesmas por critério per capita, com complementação da Secretaria de Estado da Saúde sempre que necessário.
} 
formalização do contrato de rateio, instituído por meio da Lei no $11.107 / 2005$, porém criando arranjos distintos. Em pelo menos dois dos casos analisados na saúde, no caso do consórcio de saneamento destinado ao aterro sanitário e nos três vinculados ao desenvolvimento socioeconômico, o contrato de rateio se restringiu às despesas fixas regulares da estrutura de funcionamento do próprio consórcio, sendo complementado com parcelas adicionais de recursos variáveis, que os municípios transferem para os consórcios como pagamento por serviços prestados nas modalidades e quantidades destinadas a cada um. A possibilidade de quantificação dos procedimentos de saúde realizados ou do lixo sólido destinado ao aterro sanitário favorece a complementação da contribuição de cada associado por meio de uma parcela de contribuição variável, da mesma forma que os projetos contratados nos consórcios de desenvolvimento socioeconômico, ainda que cada um possa incorporar critérios próprios dependendo da natureza das utilidades envolvidas. Em três dos nove consórcios analisados, entretanto, houve variações. Em dois dos casos de consórcios de saneamento, aqueles cujo objeto se vincula ao tratamento da água, foi encontrado, pelas respectivas assembleias, um critério genérico - o número de ligações de água - que permitiu estimar os serviços prestados pelo consórcio, a partir de valores praticados no mercado, no próprio contrato de rateio. No caso de um dos consórcios de saúde, incluindo o atendimento móvel de urgência/emergência, não encontramos nos documentos de regulamentação interna alguma referência a pagamentos adicionais ao rateio.

Postos esses elementos, o estudo aponta para algo próprio à natureza das associações voluntárias entre governos locais como os consórcios: seus sistemas de distribuição de benefícios e custos são consistentes com a disposição dos governos à maximização da destinação útil dos recursos financeiros, mesmo que o sentido de utilidade diga respeito à realização de objetivos diversos na administração pública. ${ }^{13}$ Os referidos sistemas cumprem o papel de equacionar benefícios ofertados e custos atribuídos aos associados, viabilizando a associação ao evitar o choque entre os interesses de maximização dos diversos associados.

Por outro lado, a equalização entre benefícios e custos auferidos por cada um realiza, em alguma medida, a lógica das relações de mercado em que paga-se pelo que se tem, tornando pouco provável que associações desta natureza se dediquem a resolver problemas distributivos ou em dimensão regional, o que demandaria, no limite, transpor o campo dos acordos voluntários em direção às escolhas políticas no âmbito de coletividades mais abrangentes que os governos locais. Não parece razoável supor que gestores municipais cedam recursos disponíveis para suas populações a outros municípios em nome da promoção do bem de uma comunidade de referência mais ampla como a da região, do estado ou do país, no que entendemos aqui ser improvável a inclusão de determinadas políticas públicas na agenda dos consórcios intermunicipais.

\footnotetext{
${ }^{13}$ Este pressuposto, que alimenta a referida hipótese, está ancorado na discussão no campo da Public Choice sobre o comportamento rent seeking dos agentes governamentais, em que não importa se os fins a serem viabilizados sejam o sucesso eleitoral, o desvio para o partido ou para interesses privados ou, até mesmo, a viabilização de um projeto social.
} 


\section{Considerações finais}

Neste trabalho abordamos aspectos relacionados à economia política dos consórcios intergovernamentais, tema ainda pouco presente na literatura brasileira sobre o assunto.

Entendendo que governos envolvidos não são indiferentes aos patamares de custos e de benefícios envolvidos na constituição dos consórcios, tomamos por hipótese central que, para promover a ação coletiva na produção dos valores compartilhados, as formas institucionais devem conter dispositivos que equalizem a distribuição dos mesmos custos e benefícios entre os membros. Neste trabalho, a presença de tais dispositivos foi encontrada em praticamente todos os casos estudados, mas, considerando as diferentes áreas governamentais, foi percebido que os valores públicos compartilhados reúnem características que afetam as condições para distribuição dos benefícios entre os consorciados.

Em alguns casos, há um limite máximo de produção conjunta para estes valores, o que requer estabelecer previamente os limites máximos de benefícios a serem distribuídos a cada um, o que é possível quando os mesmos valores são fracionáveis e quantificáveis. Mas tal previsão nem sempre é possível, assim como nem sempre é possível prever a oportunidade do consumo pelos associados — o que ocorre em serviços de urgência e emergência médica ou no compartilhamento de um serviço de manutenção de equipamentos — , podendo levar a distribuições aleatórias de valores entre os associados, beneficiando, eventualmente, mais a uns que a outros. Desse modo, a incerteza quanto aos níveis auferidos ou à oportunidade do beneficiamento para os associados poderia dificultar conclusão de barganhas na definição das regras de compartilhamento dos custos entre os associados.

Assim, sob os marcos constitucionais e legais vigentes, identificamos a formação de dois padrões de compartilhamento de custos e benefícios para os consórcios intermunicipais estudados em três áreas governamentais. Sob um primeiro, a diferenciação entre a participação dos associados nos custos do consórcio se dá por meio de contratos complementares que permitem estipular sua participação no consumo por meio de aferição de unidades benefício ex post (consultas médicas, exames, toneladas de lixo sólido processadas ou outros serviços opcionais), sendo o contrato de rateio restrito a despesas fixas para assegurar seu funcionamento. Sob o segundo padrão, o próprio contrato de rateio introduz um critério equalizador entre a participação dos associados nos benefícios e sua participação nos custos, como no caso da adoção do número de ligações de água em residências ou estabelecimentos comerciais em consórcios de saneamento focados no seu fornecimento.

Sob ambos os padrões, a função equalizadora se mostra crucial para a estabilização das parcerias, evitando choques de interesses entre associados. Porém percebemos que ao fazê-lo ela termina por estabelecer uma lógica similar à de mercado, onde cada um paga pelo que consome. Por um lado, portanto, tal função equalizadora reduz a incerteza quanto à ocorrência de comportamentos free riders ou de apropriações de benefícios por uma parte dos associados, afetando o cálculo de todos em sentido favorável à cooperação, a ponto de evitar que divergências na dimensão distributiva inviabilizem a dimensão produtiva. E aqui, se é verdade que a opção por estratégias cooperativas não é incondicional, a função equalizadora opera no 
sentido de oferecer a cada um a garantia de que os outros também irão cooperar. Mas, por outro lado, ela impõe limites. Torna-se pouco provável que consórcios intergovernamentais venham desempenhar outras funções solidárias, como resolução de problemas distributivos em perspectiva regional, uma vez que os consórcios se tornam instrumento para realização dos interesses comuns dos governos envolvidos, mas não dos interesses coletivos da totalidade territorial abrangida.

\section{Referências}

ABRUCIO, Fernando L.; RAMOS, Mozart N. (Org.). Regime de colaboração e associativismo territorial: arranjos de desenvolvimento da educação. São Paulo: Fundação Santillana, 2012.

ABRUCIO, Fernando L.; SOARES, Márcia M. Redes federativas no Brasil: cooperação intermunicipal no Grande ABC. São Paulo: Fundação Konrad Adenauer, 2001.

AXELROD, Robert; KEOHANE, Robert O. Achieving cooperation under anarchy: strategies and institutions. World Politics, v. 38, n. 1, p. 226-254, out. 1985. Disponível em: <www.jstor.org/ stable/2010357>. Acesso em: 22 maio 2012.

BRASIL. Câmara dos Deputados. Constituição da República Federativa do Brasil de 1967. Brasília/ DF. Disponível em: <www.inap.mx/portal/images/pdf/lat/brasil/constitucion\%20de\%20brasil\%20 1967.pdf>. Acesso em: 3 out. 2012.

BRASIL. Câmara dos Deputados. Constituição dos Estados Unidos do Brasil, de 10 de novembro de 1937. Disponível em: <http://bd.camara.gov.br/bd/bitstream/handle/bdcamara/1765/ constituicao_1937_texto.pdf?sequence=4>. Acesso em: 5 out. 2012.

BRASIL. Câmara dos Deputados. Emenda Constitucional no 1, de 1969. Brasília: Biblioteca Digital da Câmara. Disponível em: <http://bd.camara.gov.br/bd/bitstream/handle/bdcamara/1738/ Emenda_01_1969.pdf?sequence=2>. Acesso em: 24 abr. 2013.

BRASIL. Ministério da Saúde. Estados com consórcio em saúde constituído de acordo com as informações das Secretarias de Estado da Saúde em junho 2008. Brasília, 2008. Mimeografado.

BRASIL. Presidência da República. Decreto n 6.017, de 17 de janeiro de 2007. Regulamenta a Lei no 11.107 , de 6 de abril de 2005, que dispõe sobre normas gerais de contratação de consórcios públicos. Disponível em: <www.planalto.gov.br/ccivil_03/_ato2007-2010/2007/decreto/d6017. htm >. Acesso em: 14 out. 2012.

BRASIL. Presidência da República. Lei no 11.107, de 6 de abril de 2005. Dispõe sobre normas gerais de contratação de consórcios públicos e dá outras providências. Disponível em: <www.planalto. gov.br/ccivil_03/_ato2004-2006/2005/Lei/L11107.htm>. Acesso em: 12 jun. 2005.

BRASIL. Senado Federal. Constituição da República Federativa do Brasil de 1988. Texto consolidado até a Emenda Constitucional no 70 de 29 de março de 2012. Brasília/DF, 2012. Disponível em: <www.senado.gov.br/legislacao/const/>. Acesso em: 6 out. 2012. 
BRASIL. Senado Federal. Decreto $n^{\circ}$ 23.611, de 20 de dezembro de 1933. Revoga o decreto legislativo no 979, de 6 de janeiro de 1903 e faculta a instituição de consórcios profissionais-cooperativos. Brasília/DF. Disponível em: <www6.senado.gov.br/legislacao/ListaPublicacoes.action?id=46855 \&tipoDocumento=DEC\&tipoTexto=PUB $>$. Acesso em: 7 out. 2012.

CEPAM. Fundação Prefeito Faria Lima. Consórcios intermunicipais de desenvolvimento: mudando para sobreviver. In: CONSAD, 2009, Brasília. Disponível em: <www.cepam.sp.gov.br/arquivos/ artigos/6_CIs_090504\%20padronizado\%20rev_02-Consorcio\%20Carminha.pdf >. Acesso em: 25 abr. 2013.

CRUZ, Maria do Carmo M. T.; ARAÚJO, Fátima F.; BATISTA, Sinoel. Consórcios numa perspectiva histórico-institucional. Cadernos Adenauer XII. Municípios e Estados: experiências com arranjos cooperativos, Rio de Janeiro, n. 4, p. 111-124, 2011.

CUNHA, Rosani E. Federalismo e relações intergovernamentais: os consórcios públicos como instrumento de cooperação federativa. Revista do Serviço Público, Brasília, v. 55, n. 3, p. 5-36, 2004.

DALLABRIDA,Valdir R.; ZIMERMANN, Viro J. Descentralização na gestão pública e estruturas subnacionais de gestão do desenvolvimento: o papel dos consórcios intermunicipais. Revista Brasileira de Gestão e Desenvolvimento Regional, São Paulo, v. 5, n. 3, p. 3-28, set./dez. 2009.

GOHN, Maria da Glória. Teoria dos movimentos sociais. São Paulo: Loyola, 2004.

IBGE. Cidades @. Dados do Censo 2010 e extensão territorial dos municípios. Rio de Janeiro, 2010. Disponível em: <www.ibge.gov.br/cidadesat/topwindow.htm?1>. Acesso em: 5 jun. 2013.

IBGE. Instituto Brasileiro de Geografia e Estatística. Perfil dos municípios brasileiros/2009. Rio de Janeiro: IBGE, 2010. Disponível em: <www.ibge.gov.br/home/estatistica/economia/perfilmunic/ defaulttab3_coleta.shtm>. Acesso em: 20 jan. 2013.

IBGE. Instituto Brasileiro de Geografia e Estatística. Perfil dos municípios brasileiros/2011. Rio de Janeiro: IBGE, 2012. Disponível em: <www.ibge.gov.br/home/estatistica/economia/perfilmunic/ defaulttab3_coleta.shtm>. Acesso em: 20 jan. 2013.

IBGE. Instituto Brasileiro de Geografia e Estatística. Perfil dos municípios brasileiros/Gestão Pública 2002. Rio de Janeiro: IBGE, 2005. Disponível em: <www.ibge.gov.br/home/estatistica/economia/ perfilmunic/defaulttab3_coleta.shtm>. Acesso em: 20 jan. 2013.

IBGE. Instituto Brasileiro de Geografia e Estatística. Perfil dos municípios brasileiros/Gestão Pública 2005. Rio de Janeiro: IBGE, 2006. Disponível em: <www.ibge.gov.br/home/estatistica/economia/ perfilmunic/defaulttab3_coleta.shtm>. Acesso em: 20 jan. 2013.

IPEA. Brasil em desenvolvimento: Estado, planejamento e políticas públicas. Brasília: Ipea, 2010.

KNIGHT, Jack. Institutions and social conflict. Cambridge: Cambridge University Press, 2001.

LEVAGGI, Rosella. Decentralized budgeting procedures for public expenditure. Public Finance Review, v. 30, n. 273, p. 273-295, 2002.

LIMA, Ana P. G. Os consórcios intermunicipais de saúde e o Sistema Único de Saúde. Cad. Saúde Pública, Rio de Janeiro, v. 16, n. 4, p. 985-996, out./dez. 2000. 
LIMA, Ana P. G.; PASTRANA, Rosa M. S. Relatório de pesquisa: diagnóstico da situação atual de consórcios intermunicipais de saúde no Brasil. Brasília: Opas, 2000.

LÖFFLER, Elke. A gestão da responsabilização nas parcerias intergovernamentais. Revista do Serviço Público, v. 51, n. 2, p. 5-34, abr./jun. 2000.

MACHADO, Gustavo G.; DANTAS, Caroline B. Constituição de consórcios públicos e implicações da Lei no 11.107/2005 nas associações intermunicipais anteriores. In: PIRES, Maria C. S.; BARBOSA, Maria E. B. Consórcios públicos: instrumento do federalismo cooperativo. Belo Horizonte: Fórum, 2008. p. 165-192.

MACHADO, José A. Políticas públicas descentralizadas e problemas de coordenação: o caso do Sistema Único de Saúde. Tese (doutorado em ciências políticas) — Faculdade de Filosofia e Ciências Humanas, Universidade Federal de Minas Gerais, Belo Horizonte, 2007. Disponível em: <www. bibliotecadigital.ufmg.br/dspace/bitstream/1843/VCSA-7GYV99/1/tese_final.pdf>. Acesso em: 12 out. 2012.

MILLER, Gary; HAMMOND, Thomas. Why politics is more fundamental than economics. Journal of Theoretical Politics, v. 6, n. 1, p. 5-26, 1994.

OATES, Wallace E. Toward a second-generation theory of fiscal federalism. International Tax and Public Finance, v. 12, n. 4, p. 349-373, 2005.

OLSON JÚNIOR, Mancur. The logic of collective action: public goods and the theory of groups. Nova York: Schocken Books, 1968.

PIRES, Maria C. S.; BARBOSA, Maria E. B. Consórcios públicos: instrumento do federalismo cooperativo. Belo Horizonte: Fórum, 2008.

RAVANELLI, Paula. Consórcios públicos: os desafios do fortalecimento de mecanismos de cooperação e colaboração entre os entes federados. In: CONGRESSO CONSAD DE GESTÃO PÚBLICA, III, Brasília, 2010. Disponível em: <www.consad.org.br/sites/1500/1504/00002002.pdf>. Acesso em: 28 maio 2013.

REIS, Fábio W.; CASTRO, Mônica M. M. Democracia, civismo e cinismo: um estudo empírico sobre normas e racionalidade. $R B C S$, v. 16, n. 45, p. 25-46, 2001.

RIBEIRO, José M.; COSTA, Nilson R. Regionalização da assistência à saúde no Brasil: os consórcios municipais no Sistema Único de Saúde. Planejamento e Políticas Públicas, Rio de Janeiro, n. 22, p. 173-220, 2000.

ROCHA, Carlos V.; FARIA, Carlos A. P. Cooperação intermunicipal, reterritorialização da gestão pública e provisão de bens e serviços sociais no Brasil contemporâneo: a experiência dos Consórcios de Saúde de Minas Gerais. Cadernos Metrópole, São Paulo, n. 11, p. 73-106, 2004.

SANTOS, Lenir. Consórcio administrativo intermunicipal: aspectos gerais. Suas especificidades em relação ao sistema único de saúde. Secretaria de Políticas Públicas do Ministério da Saúde, 2002. Disponível em: <www.nesc.ufg.br/uploads/19/original_CIS_Lenir_Santos.pdf>. Acesso em: 27 abr. 2013. 
SCHARPF, Fritz W. Games real actors play: actor-centered institucionalism. Boulder: Westview Press, 1997.

SCHELLING, Thomas C. La estrategia del conflicto. Madri: Tecnos, 1964.

SCHNEIDER, Anamaria. Os consórcios intermunicipais de saúde no estado do Rio de Janeiro. Physis - Revista de Saúde Coletiva, Rio de Janeiro, v. 11, n. 2, p. 51-66, 2001.

TSEBELIS, George. Jogos ocultos: escolha racional no campo da política comparada. Tradução de Luiz Paulo Rouanet. São Paulo: Editora da Universidade de São Paulo, 1998.

José Angelo Machado é doutor em sociologia e política pela Universidade Federal de Minas Gerais e professor adjunto do Departamento de Ciência Política da UFMG. E-mail: joseangelo@fafich.ufmg.br.

Marta Leone Costa Andrade é graduada em gestão pública pela Universidade Federal de Minas Gerais. E-mail: martaleone@yahoo.com. 